\title{
The Myth and Reality of Rukiye Hanim in the Context of Turkish Malay Relations (1864-1904)
}

\author{
Mehmet Ozay, ${ }^{*}$ Ekrem Saltık*
}

\begin{abstract}
The present article investigates the identity, partial biography, and relations of Rukiye Hanim. She is recognized as the grandmother of three significant families who have been playing distinguished roles in politics and academics in Malaysia. Rukiye Hanim with her sister Hatice Hanim are believed to have been presented as concubines by Babussaade, the Palace in Constantinople, to Sultan Abu Bakar of Johor in the closing decades of the 19th century. It is significant here to pin down that this article grew out of some concerns upon the discourse argued by circles around the relations of Rukiye Hanim. The present writers urge that the established discourse creates an imagined memory, explicitly or implicitly, borrowing the concept from Benedict Anderson, related to this lady. This article will provide some details on the concubine, Rukiye Hanim who seems to be the main actor to set aright imagined misconceptions. This research relies on primary data particularly from oral information of the living descendants of Rukiye Hanim. Besides, the present writers conduct comparative understanding of the secondary sources to re-examine the mainstream discourse upon Rukiye Hanim written in Turkish, Malay and English languages. This research found that the concubines are not connected organically with the Ottoman Palace family, they are instead commoners and members of other nations. This sensational imagination has turned out to be a sort of historical fact structured by certain groups, both in Turkey and Malaysia, and it has been functionalized to establish historically the relations between modern Turkey and Malaysia.
\end{abstract}

Keywords: Rukiye Hanim, Ottoman State, Johor Sultanate, Concubine, Historical Imagination.

Öz: Bu makale Rukiye Hanim'ın kimliği, kısmen biyografisi ve ilişkilerini ele almaktadır. Rukiye Hanim, modern Malezya'nın siyasi ve akademi dünyasında kayda değer rol almış üç ailesinin 'büyükannesi' olmasıyla tanınıyor. 19. yüzyılın sonlarına doğru, kardeşi Hatice Hanim’la birlikte Johor Sultanı Ebubekir'e Osmanlı Sarayı́nın hediyesi olarak gönderildiği ileri sürülmektedir. Bu makale, kimi çevrelerin Rukiye Hanim’ın ilişkileri bağlamında ortaya attıkları görüşler üzerine gündeme geldi. Bu çalışmanın yazarları bu Hanim hakkında gündeme getirilen mevcut anlatıları, Benedict Anderson'un 'icad edilmiş hafıza' kavramına atfen dikkatlere sunmaktadır. Çalışmada, bir dizi hatalı imgeler etrafında kurgulandığı ileri sürülen Rukiye Hanim’la ilgili bazı detaylara dikkat çekmektedir. Bu çerçevede, çalışma, bugüne kadar kaleme alınmış birincil kaynaklar kadar, Rukiye Hanim'ın hayattaki yakınları ile yapılan sözlü anlatıya dayanmakta ve içerisinde Türkçe, Malayca ve İngilizce kaleme alınan eserler karşılaştırmalı olarak değerlendirilmektedir. Bu araştırma, söz konusu cariyelerin Osmanlı Saray ailesine mensup olmadığını, aksine başka bir ulusa mensup sıradan kişiler olduğunu bulgulamaktadır. Rukiye Hanim kimliği etrafında oluşturulan sansasyonel imaj, Türkiye ve Malezya'da bazı belirli çevrelerin tarihi gerçekleri farklı yorumlamalarına dayanmakta ve bu imaj ile modern Türkiye ve Malezya ilişkileri tarihsel olarak örüntülenmek istenmektedir.

Anahtar Kelimeler: Rukiye Hanim, Osmanlı Devleti, Cohor Sultanlığı, Cariye, Tarihsel İmaj.

* Independent Reseacher, Kuala Lumpur, Malaysia.

Correspondence: mehmedozay@gmail.com

** Ph.D Program, Sakarya University Department of Sociology

Correspondence: ekremizm@hotmail.com.

D0I: dx.doi.org/10.12658/human.society.5.9.M0116

İnsan ve Toplum, 5(9), 2015 


\section{Introduction}

The socio-historical connections between the Ottomans and some Southeast Asian Sultanates are known to some extent. Hence, it cannot be argued that the whole scope of this relation has been uncovered by academia. In particular, academics in related areas have elaborated, to a limited extent, these connections in their research. Aceh-Ottoman political relations, for example, have been documented in detail by various researchers in the last few decades. Aside from political and diplomatic links between the Ottoman State and some political entities in Southeast Asia, informal links were also built through marriages. The individuals in and in proximity to such marriages sometimes, though not always, emerged as significant actors on the political stage. Thus, historical attention was later paid to these marriages in support of the aims of certain political circles. Hence, the life circles and experiences of the premier actors surrounding these marriages are also significant in themselves.

In this context, it is right to ask the following questions: Who are Rukiye Hanim and Hatice Hanim? To what extent were the ladies connected to the Ottoman palace family? How is their existence perceived by various circles in Turkey and Malaysia particularly in the context of political ties between both countries? Because of these questions, the present article is to reinvestigate the identity, partial biography, and relations of two concubines who are believed to have been presented by Babussaade -the Palace in Constantinople- to Sultan Abu Bakar of Johor in the closing decades of the 19th century. It is also significant here to pin down that this article has grown out of some concerns on the efforts of some circles, both in Turkey and Malaysia, to create an imagined memory, borrowing from Benedict Anderson, explicitly or implicitly, related to these concubines (Özcan, 2011). These circles seem to be different in terms of their end, but they are committed to the same vehicle, say, the concubine issue. Furthermore, neither has the concubine issue been the subject of a separate inquiry, nor has there been any profound account of it. Instead, particularly Rukiye Hanim' is included in some accounts owing to her being the 'mother' of some 'distinguished' individuals in Johor Sultanate and whose descendants became statesmen and highest level bureaucrats both during the last decades of the Sultanate of Johor and in modern Malaysia.

This subject matter becomes critical because the concubine issue is assumed to have underlied socio-political foundations or relations between the two nations, say, Turks and Malays ${ }^{2}$ or between the two states, The Ottoman State and The Johor Sultanate without any related developments observed. As a historical continuity, this relationship seems to have been perpetuated as mentioned concisely above, though it is superficial owing to each respective country's domestic political problems. This forms a convincing argument for the academic necessity to overcome the disputed and controversial accounts, to some extent, of both Turkish and Malaysian circles.

All in all, we can assume that this paper is based on a comparative understanding and has a critical approach to the issue. In this paper, we will take into account some distinguished

1 The name is generally written as Roquaiya, but also Rogayah and Rugayyah in English texts from Singapore and Malaysia. As an exception, Ong writes this name as Rusaya (See.: Siew Im, 1998, p, 19).

2 Here 'Malays' refers to the people living in the Malay Peninsula. 
sources penned in Turkish, English, and Malay languages which are believed to be the most reliable documents about these two concubines. While some of them are based on academic research, others were the result of the interviews with the descendants of Rukiye Hanim and their close family members or friends. Among these works Legacy of Honour by Zainah Anwar, Ramlah Adam, and Pamela Ong See is of prime importance. Interviewed individuals included Datuk Jaafar Onn, the son of Dato Onn; Zainah Anwar, whose father was a close friend to Dato Onn, and Mohammed Abid, the personal aide of Dato Onn. This article will provide details on the concubines, particularly Rukiye Hanim who seems to be the main actor to set aright imagined misconceptions.

\section{Overview of Concubinage}

At this juncture, though Rukiye and Hatice Hanim were called concubines, it should be emphasized that we do not know the exact category under which these two women were given. The category is crucial because it is related to the authenticity of the accounts exercised aligned with the identities of these ladies. Further, the descendants of their marriages left a legacy in the history of Johor Sultanate, from the era of their arrival and on into modern Malaysia. Some circles highlight these relations to reach the conclusion of an imaginary political situation such as a sort of pro-Turkish political party and to some or larger extent, the expansion of Pan-Islamism in the Malay world (Armağan, 2007; Aymalı, 2014; Saltık, 2012b; Şara Şatana, 2012) ${ }^{3}$ and a cause to be nationally proud owing to the so-called Turkish origins of the concubines. There are at least two misconceptions in this way of thinking. The first is related to the real identity of the concubines. The second is the impact of these marriages on any significant political awareness among the Muslims or the palace circles during the mentioned era in the Malay Peninsula. Furthermore, to overcome the misunderstandings and ignorance or intentional conspiracies that pervaded the minds of some interest groups, the issue of concubines should be elaborated in further detail.

Within the Ottoman system of slavery there were various categories such as halayık (female slave), cariye or odalık (female slave, elite hayalık, or concubine) (Zilfi, 2005, p. 133). We will deal with the issue of socio-cultural and political construction efforts pertaining to the "identity" of these two concubines in both countries. With regard to the cariyeship, it is unknown whether the two concubines were given their freedoms and got married as free women, were offered any dowry or property, and so on. This is a very crucial point, since the legal status of concubines did not have any equality with a free marriage status. As it

3 Note: Armağan, by the title of the article, implicitly asserts the 'Ottoman identity' of Rukiye Hanim. He brings forward that the political party founded by Dato Onn was a pro-Turkish movement. In addition, the writer depicts the story established around Rukiye Hanim particularly via her marriages, as the sample of a very close relations between Turkey and Malaysia. In addition, Aymalı enunciates that the marriage of Rukiye Hanim with Ungku Abdul Majid was not an ordinary one, instead the one which is regarded as a sort of sign of political establishment between the Ottoman State and the Malay sultanates. According to the writer, the Malay -here referring to the Malay sultanates- were ready to accept the protection of the Ottoman States. Another point is highlighted pertaining to the marriage of Sultan Abu Bakar with Hatice Hanim. This marriage is put forward as cementing the kinship relations between the Ottomans and the Malays. It seems that there are certain repetitions in all the referred writings pertaining to the political proximity between Turkey and Malay political establishment. 
is observed in the European context, concubinage was regarded as a "sexual relationship, lacking of legal protection for the woman and her children, and easily terminated" (Stafford, 1998, p. 63). On the other hand, the concubines were in one of the three parts of the 'Harem', which was called 'labor class' in the Ottoman Palace (Brookes, 2008, p. 3; Demir, p. 81). ${ }^{4}$

What sort of role they were prescribed in the Palace or the elites' houses during their marriages in Johor, how they overcame the language barrier with the Johorians, whether they became transmitter of any Middle Eastern/Ottoman cultures such as etiquette or cuisine to Johor Palace and social life are also interesting points which require further research.

\section{Origins of the Concubines}

A personal anecdote seems fitting at this point. During a discussion with a former student of Prof. Dr. Syed Naqib Al-Attas at Universiti Kebangsaan Malaysia (UKM), Bangi, sometime in April, 2010, the concubine issue was raised. Thus, the lecturer expressed a personal account, having been closer to Prof. Dr. Al-Attas and having witnessed a crucial event. The lecturer recounted that a representative of a Turkish group had previously approached him to arrange an interview with Prof. Dr. al-Attas about his familial relations, particularly the relation with Rukiye Hanim. There is no doubt that this was an attempt to highlight populist ambition in Turkey which is highlighted in terms of the Ottoman's political expansion in Southeast Asia (Özcan, 2011). ${ }^{5}$ When the Al-Attas family was informed about this attempt, they kindly declined the interview arguing that though Rukiye Hanim was the family's grandmother, she neither belonged to the Ottoman palace family nor was she originally of Turkish blood.

This anecdote is a very crucial indication about the reality of the origin of Rukiye Hanim and her sister, Hatice Hanim. Furthermore, this indication appears to be supported by other attempts conducted by Hussein Onn, the third Prime Minister of Malaysia, between the years 1976-1981, who kept alive an interest about the origins of his grandmother, Rukiye Hanim, and ordered an investigation into them.

Datuk Jaafar Onn, the younger brother of Hussein Onn and another grandson of Rukiye Hanim also confirmed during an interview that there has not been any significant information revealed from his late brother's attempt and scrutinization (Datuk Jaafar Onn and his cousin Mohammad Abid, personal communication, February 21, 2014, Petaling Jaya). Hussein Onn approached Turkish authorities for information pertaining to the origins of his grandmother during his official visit to Turkey as the Prime Minister of Malaysia. ${ }^{6}$

4 Note: It should be emphasized that Rukiye and Hatice Hanim were not in the third part which belonged to the Sultan's family. See.: Özcan Demir, (n.d.).

5 Note: Starting from the title of the text written as 'Malezya'nın Osmanlıları' which can be translated as Ottomans of Malaysia does not reflect the reality about the issue and its relation with the Ottoman. The text has some other misleading information regarding the dates and information such as there were 'three sons' born from the marriage of Rukiye Hanim with Abdul Majid, the brother of Sultan Abu Bakar. However, all authentic sources refer to two sons. In fact, this paper needs to be analytically considered in another paper with some other relevant works.

Tun Hussein Onn paid an official visit to Turkey in 1977 (Perdana Leadership Foundation, 1983). 
The Turkish counterparts failed to supply any satisfactory reply. It is a manifest fact that whatever PM Hussein Onn ultimately discovered was not sufficiently satisfying to be publicly revealed (Siew Im, 1998, p. 20).? It is possible that he might have thought that the result of the investigation would impair his fame. The attempt of Hussein Onn underpins the vagueness of the origins of Rukiye Hanim. In a nutshell, the unsatisfying result of this attempt is assumed to be complementary to the account of Al-Attas family.

\section{Circassia}

The origins of the concubines are a starting point in understanding their lives. Though this issue will be reconsidered later, here it is worth having the origins of the concubines taken for granted as being Chechnyan from the Circassia region of the West Asia. Circassia, lying on the eastern part of the Black Sea, was historically under the political sovereignty of the Ottoman State. Circassian rulers conducted slave business including Circassian girls and women (Popper, 1957, p. 11). In some accounts it is argued that, particularly during the late decades of the 19th century, while the region was under the threat of the Russian Empire the Circassian families voluntarily sold or -sent by some accounts- their daughters to Constantinople where they believed Circassian women were given more attention because of their beauty.

Datuk Jaafar Onn, grandson of Rukiye Hanim and his cousin Muhammad Abid highlighted this geographical connotation in terms of unspecified region from which it is assumed Rukiye Hanim and Hatice Hanim came. He assumed that the sisters were originally somewhere between the Ottoman-Russian border either from Georgia, Circassia or another similar region (Datuk Jaafar Onn and his cousin Mohammad Abid, personal communication, February 21, 2014, Petaling Jaya).

Attempts have been made to find an official or unofficial letter/document related with the Rukiye Hanim case in the Başbakanlık Ottoman Archive in Istanbul. To date, no such document has been located to reveal either the identity of Rukiye Hanim or the mechanism by which she and her sister were sent to Singapore. All that is currently known about the voyage is that a male accompanied them (Datuk Jaafar Onn and his cousin Mohammad Abid, personal communication, February 21, 2014, Petaling Jaya). This absence of information has been highlighted to human resources such as Datuk Jaafar Onn, his cousin Mohammad Abid, and Zainah Anwar. But these resources have failed to pronounce any satisfactory response.

\section{A Discovery of the Origin of Rukiye Hanim}

In variety of sources, there are distinct explanations on the origin and race of Rukiye Hanim. Among them, the most striking is of her being a Turk. For instance, Mohammad Tajuddin in

7 Note: The same unsuccessful attempt was conducted by some representatives of Yayasan Warisan Johore during their visit to Başbakanlık Osmanlı Arşivleri in Istanbul. (Zulkarnain, the head of History Department of Yayasan Warisan Johor, personal communication, December, 2010, Johor Bahru) 
his work on Dato' Onn and Zainah Anwar clearly argue that Rukiye Hanim was a Turk (Haji Abdul Rahman, 1987, p. 1; Anwar, 2011, p. 30, 63). Though it is known that Zainah Anwar interviewed with descendants of Rukiye Hanim, Mohammad Tajuddin did not clarify from where he collected the related information.

A contradictory argument from mainstream acceptance about the background of Rukiye Hanim is mostly related to the accounts of Pamela Ong. She expresses that though there is no doubt that Rukiye Hanim came from a good family, there is no exact information about her background. Further, she asserts that the multiple speculations about Rukiye Hanim's origins are the source of dispute among researchers. Trying to highlight this aspect, Ong articulates some distinct views that Rukiye Hanim might have been on the one hand Turk or Russian, on the other hand Armenian or Caucasian. Ong muses on the possibility that she might have been a Muslim-born Russian (Siew Im, 1998, 19-20). This is a similar assumption to that of Datuk Jaafar Onn and his cousin Mohammad Abid.

But this contention causes a contradiction to the practice of concubine institution in the tradition of the Ottoman Palace. As far as it is known, the Sultans never kept Muslim-born women as concubines in the Harem. In this matter, it is strongly argued that Abdulhamit II could not have presented any Muslim-born women to the Sultan of Johor.

Another conundrum related to her possible Caucasian background is that it refers not to a country or race, but to a region. It can be assumed that the reason for the diversification of her origin is because of Rukiye Hanim's own accounts on her background. When the accounts of Pamela Ong are read in detail, it appears that Pamela Ong reached a conclusion of the different possibilities of Rukiye Hanim's origin on the basis of her research. Ong alludes that Rukiye Hanim might have informed different people around her about her background according to different time and place (Siew Im, 1998, p. 19-20). But again here, detailed accounts regarding Ong's sources and the basis for reaching her conclusions cannot be found.

One of Pamela Ong's strong references remarks that Hussein Onn, a grandson of Rukiye Hanim and the third Prime Minister of Malaysia, launched a comprehensive study in order to resolve the dispute about his grandmother's origin. As part of this investigation, Hussein Onn reached a cousin. However, the cousin's identity was not revealed and Onn concluded this attempt by cancelling all his relations with this kin. Onn's actions might be regarded as proof that does not support the Turkish origin of Rukiye Hanim. At this juncture, Ong speculates that Rukiye Hanim was a descendant of another nation and all of her family members lost their lives during the event in 1917 (Siew Im, 1998, p. 20). Such speculation would require a complete research to be conducted.

Additionally, there is a notable reference to the origin of Rukiye Hanim on the basis of an interview with Azizah, the daughter of Dato Onn conducted on 9 and $13^{\text {th }}$ October 1969 (!) in the latest work on the Onn family, published in 2012. Azizah expressed that her grandmother was originally Turk in this interview (A. Abdullah, 2004, p. 34; Husain, 1985, p. 5). Though Hussein Onn, Azizah and Datuk Jaafar Onn were the children of Dato Onn, their conclusions on the origin of their grandmother seem totally different. In terms of this, it ought to be remembered that an official body from the "Yayasan Warisan Johor" from 
Johor State paid a visit to Istanbul in 2007 (Zulkarnain, the head of History Department of Yayasan Warisan Johor, personal communication, December, 2010, Johor Bahru). As a concrete attempt, this group of intellectuals from Johor paid a visit to the Ottoman Archive in Istanbul with the intention of rediscovering some documents connected with the concubines. Unfortunately, as mentioned by one of the participants of this visit, they could not reach the strong supportive documents that they had anticipated. If the aforementioned accounts are considered in for authenticity, there is no doubt that the Prime Minister's attempt must be given priority and his final decision to close the matter cannot be underestimated. Hence, there is no means by which to currently resolve the disputes on the identity of Rukiye Hanim.

\section{Imagined Identities, Politicised Marriages and Meta Narrative}

The late decades of the 19th century witnessed the marriages of two sisters sent by the Ottoman palace to the Johor Sultanate. While we will try to conceive how the presence of these ladies was perceived by both Turkish and Johorians, it is also crucial to employ a degree of caution. There is no doubt that this subject is an interesting starting point for the divergence between imagination and reality. We will try to cast light upon how these concubines are perceived by both Turks and particularly Johorians/Malaysians throughout various written sources.

This connection between the two late sultanates seems to continue particularly in modern Malaysia rather than in Turkey. The marriages and their political connotations have established a 'social hierarcy' in Malay society, particularly a political elite emerged from the Johor State. In particular, the marriages of Rukiye Hanim and the descendants of these marriages becomes the source of extol among some circles including prominent political elite families. Furthermore, these marriages have been the subject of a misleading interpretation. In this context, these two concubines are particularly underscored by some circles to mark the so-called politico-Islamic intervention, say, a means of Pan-Islamic influence of the Ottoman administration into the Malay world (Saltık, 2011, 2012a).

This issue seems crucial since some circles have portrayed particularly Rukiye Hanim in a mystical aura by asserting her as a representative of an Ottoman family and a sort of channel connecting the Ottomans and Johor Palace. Though her origin was from the Circassian region based on the consensus as indicated above, it seems that both in Turkey and Malaysia some quarters have been trying to imaginatively give a shape to her identity and role that she supposedly exercised during her time as a member of the Johor Palace. This identity and role is not confined to familial attachments through her marriages with 'distinct' families, but is recounted in a 'meta-narrative' in order to arrive at a conclusion that she was the medium of a global-network of Pan-Islamism which is referred to by Abdulhamid II and his policies. Hence as observed hitherto, there were no congruent correspondences or interactions between the two political centres. Notwithstanding, this is a comprehensive research subject that should be dealt with in another paper. Albeit, it cannot be observed that this issue is posited in some prominent rubrics such as A.C.Milner's article on "The Impact of the Turkish Revolution on Malaya" (Milner, 1986, p. 31), Anthony 
Reid's "Nineteenth Century Pan-Islam in Indonesia and Malaysia" (Reid, 1967), and some other similar works. Still others recognize them in an "aristocratic lineage" to the Ottoman Palace in Constantinople (Abd. Samad, 2011, p. 21).

At this juncture, the context of Pan-Islamism necessitates a look into details of the agreements between the Johor Sultanate and Great Britain. Since the former was a protectorate of the latter for quite a long time (Ramanathan, 2000, p. 109). In addition, in the case of a Pan-Islamic approach, it must have been proved in relations between Johor and some other Malaya Sultanate such as Perak and Selangor. Hence, during the riots to some or larger extent in the latter sultanates, though the Sultan of Johor tried to resolve the conflict between the mentioned sultanates and the British rule in the Straits Settlements (Husain, 1995, p. 101), Sultan Abu Bakar allowed the British to use his own steamships on missions to the west coast states (Trock, 1979, p. 188-9). Additionally, though this marriage arrangement was between two Muslim political entities, it is not ignored that during the late decades of the 19th and early 20th centuries Johor Sultanate was a border state with the British government in Singapore. Though there is a certain justification that the Johor Sultanate was a sovereign state, both the close and voluntary relations with the British and the latter's eco-political considerations did not leave Johor administration to play regional and international roles independently. In regard to this, it is worth reminding of a strong proof of the hierarchic relations established since the early encounters between Johor and Great Britain.

In terms of this, the first two initiatives in the years of 1819 and 1824 were very determinative for the future relationship. The first agreement was signed between Sir Stamford Raffles, then Lieutenant-Governor of Bencoolen, and Tumunggung Maharajah, the ruler of Singapore, in 1819 and the second treaty proceeded again between these two political establishments in 1824. In both agreements it is clearly worded that Tumunggung "will not enter into any relations with, or let any other nation into his country other than the English" (Old Treaties, 2008, p. 136, 140). These internationally recognized treaties did not allow the Johor administration to transgress the Articles pertaining to political relations with a third party. At the same time, there are enough examples pertaining to some arrangements highlighted by some regional powers in Southeast Asia which were supposedly to have a connection to Pan-Islamism. Hence these attempts concluded in failure owing to the political decline of the Ottoman State.

\section{How are the Concubines Perceived?}

In this part, the perception of the presence of two concubines, particularly by the palace circle and the Johorians will be addressed. While there is no single vivid image of the concubines, it is sure that the Johorians who are aware of the concubines, popularize the issue and proudly denote a relation with the Ottomans asserting that these ladies were sent from the Ottoman palace family. This approach constitutes a reflection of a competition emanated by a very established historical archetype of Aceh-Turk relations which is supposed to give eminence to the Johorians. This approach reveals the lack of cultural competency, which is particularly observed in discussions with Indonesian counterparts in the sphere of the assertion in the media of ownership of cultural elements. We may 
argue that this issue as coded strongly by the Johorians to harness in the competition with their Indonesian counterparts. No doubt that these two concubines are made vehicles for the Johorians to entertain convergence with Turks which retains more meaning than a common cultural contact. In spite of the fact that there is not much significant acquaintance about the 'identity' of the concubines, this general approach is observed to have a continuity in Johor/Malay community.

The bond with the Middle Eastern power is no doubt a reference point for any state or social circle in Southeast Asia. Status was determined by the attention received from the Ottomans. In terms of this, since the Johorians are definitely aware of the AcehOttoman relations particularly popularized after the tsunami in 2004, they also attempt to deliberately develop a purport which leads to a strong bond between the Ottomans and themselves from the presence of these ladies. It can also be argued that the Johorians have a predilection to emulate the Acehnese. This can be observed in the official attempt of the Yayasan Warisan Johor which is briefly highlighted above.

It can be argued that the concubines' arrival instigated a sort of bond between two Sultanates. Though somewhat ambiguous in nature, it is at least known that this was not the result of a strong political attachment. Upon digging through memoirs and other books about the related families, particularly the ones playing pivotal roles in national political life and administration such as Onn family, the familial relations formed a sort of preponderance. The descendants of this family have showed interest to their 'blood connection' to Turkey. ${ }^{8}$ The interest is not only limited to this family but also to the interfamily marriages in Johor and Pahang that led to some extended familial relations. For instance, in the Annual Meeting of UMNO in 2011 broadcast on national TV, Najib bin Razak, the Prime Minister, accentuated this familial connection so as to prove how "strong" members were in the cabinet. ${ }^{9}$

At this juncture, it is also interesting how the presence of two concubines are perceived in Turkey. It is not logical to assert that there is a unique perception in Turkey. Nor has there been a satisfying discussion, talk or publication on the issue. The impression given in some popular accounts published in journals, newspapers, or internet pages is that certain circles have a superficial impression of the concubines (Özcan, 2011). But it stands out that some quarters have put a distinct ascription on this issue without any credentials and are preoccupied with emotionalism. Of course in this situation, discrepancies remain. Further, they also insistently overemphasize this issue being functionalized in its popularity which might be useful to support superiority inherited from the Ottomans' deed in the past.

8 There are enough references about this issue in various places in this article. Hence, Dato Onn's own statement during a political speech in Pontian stating that "I have Turkish blood" is quite unique in this context (Datuk Jaafar Onn, personal communication, February 21, 2014, Petaling Jaya).

9 Note: Prime Minister is also connected to Rukiye Hanim in a direct or indirect link as argued as follow: “... The current prime-minister of Malaysia Mohd. Najib Abdul Razak (b. 1953) has also Turkish blood from the same family tree". See.: Kayadibi, 2011, p. 201.) Zainah Anwar also stated during my interview with her that current Prime Minister of Najib bin Razak has a close relation via marriages between his and Onn's family members. See.: Özay (2012). Hence, there is a certain tendency among the public of Malaysia to regard Prime Minister Najib bin Abdul Razak as descendant of Bugis ethnicity in Malaysia. See.: "Najib an Orang bugis or an Orang Melayu" (2009), \& "Bugis" (n.d.). 
There must be some authentic criteria about the phenomenon of two concubines. Despite the fact that they argue the emergence of Pan-Islamic context via these concubines, there is unfortunately slim evidence of it. This falsity can impair not only the concept of PanIslamism, but also tarnish the image of the Ottomans to some extent. Some circles no doubt overemphasize the marriages between the concubines and its members. However, they do not pronounce the social identity of these two women, instead they seem to exert extra efforts to reach a conclusion of superiority of the Ottomans or a sort of Pan-Islamic connection between two sultanates. In a nutshell it must be argued that these circles try to reap the benefits of the so-called function of the concubines.

\section{A Simplicity of Failure}

Beyond these Malaysian writers' works there are some accounts on Rukiye Hanim in a work titled "Islamic Identity and Development: Studies of the Islamic Periphery" by Prof. Dr. Mehmet Ozay. This book takes the concubine issue into consideration in terms of its relation with the connections throughout history between Turk and Malay worlds. During his presence, it seems Prof. Ozay conducted an interview with the Al-Attas family. There is just one paragraph about this issue on page 28 (Ozay, 1990). In this small account, the writer highlights the relevant issues such as the identity of Rukiye Hanim, the year of the visit of Sultan Abu Bakar of Johor, the arrival of Rugayyah (alternate spelling used in this source) in Johor, her marriages and children, and so on. The paragraph mentions that Rukiye Hanim was originally Caucasian. This point is crucial since it reveals that the concubines were not Turkish as originally supposed and claimed by the Johorians/Malaysians. Further, being Caucasian means, in the palace context, that they were either bought from the slave markets or taken prisoner during a war. Another option is that they were presented voluntarily by their families, which is supposed to be a common practice by some groups of Caucasians during the late decades of the 19th century.

A problem with this brief account from Prof. Ozay is that it is related to some concrete dates. For instance, the Sultan of Johor did not pay a visit to either Turkey or Europe in the middle of the 1860s. It is difficult to confirm if this date is possible since various sources, some daily newspapers and the works of native researchers such as A. Rahman Tang Abdullah (2011), P. Lim Pui Huen (2009), did not mention any dates related to this very early visit. Albeit they articulate the visits conducted to Europe including few trips to Constantinople in the years of 1885 (A. R. T. Abdullah, 2011, p. 34), (1890) 1891 (Abdullah, 2011, p. 35; "Death of the Sultan of Johore", 1895, p. 2; "Johore in the Sultan's Absence", 1890, p. 13), 1893 (The Sultan of Johore in Germany", 1893, p. 3), 1895 (A. R. T. Abdullah, 2011, p. 35; "Death of the Sultan of Johore", 1895, p. 2). There are various views on the date of his visit. While Ramlah Adam, in his work titled as "Dato Onn Ja'afar", mentions that Sultan Abu Bakar visited Constantinople in 1879 (Adam, 1992, p.4), , another article asserts an exact date as 22 February 1893 on the basis of Hikayat Johor, a classical manuscript about Johor history. ${ }^{10}$ There is also one other reference arguing the mentioned visit happened in 1890 (Idris, \&

10 Sultan Abu Bakar travelled firs time to England in 1866. And the second visit was conducted in May 1885. (See.: A. R. T. Abdullah, 2011, p. 34). 
Kurtbağ, 2013)..$^{11}$ Beyond these years, there is one reference to 1892 in which Sultan of Johor was assumed that he paid a visit to Turkey (Huen, 2009, p. 82). On the other hand, Datuk Jaafar Onn argues that Sultan Abubakar visited Constantinople twice during his trips to Europe, the second visit in 1886 (Datuk Jaafar Onn, personal communication, February 21, 2014, Petaling Jaya).

There is also a problem regarding the order of Rukiye Hanim's marriages. Prof. Ozay puts it in order starting from Abdul Majid, the younger brother of the Sultan of Johor; the second is Dato Jaafar bin Mohamad and the third is Abdullah al-Attas (Ozay, 1990, p. 28). But in fact, this order must be corrected by putting in the first place the marriage with Ungku Abdul Majid, the second Al-Attas and the third Dato Jaafar.

At this juncture, it is worth reminding that the interest of the Ottomans into the developments of the Southeast Asian Muslim communities were triggered by the latter's correspondences pertaining to the political and military demands against the colonial establishments, particularly in the southern Malacca Strait. ${ }^{12}$

Nevertheless, the aforementioned contention is precisely too weak to be supported, in the light of the accounts of various sources, based on mere assumptions which hold this issue as a subject matter. So much so that, though the credentials of the issue is dubious, some circles prefer overlooking the cruciality of the transmission of Islamic Legal Code to the Sultanate of Johor almost in the same years in terms of the Islamically administrative and political interconnection (Borham, 2002) or if the Ottomans' political relations with some other regional powers such as the Sultanate of Aceh, to some extent Djambi in Sumatra and some connections in Java Island (Locher-Scholten, 1994, p. 122) are taken into consideration it would definitely denote more meaning.

\section{Concubines' Arrival in Johor}

Another crucial issue pertains to the age of Rukiye Hanim. One aspect of this issue is related to which year these two concubines arrived in Johor. Ramlah Adam insists that Rukiye Hanim, presented by Abdulhamit II, was brought to Johor when she was 15 years old in the year 1879 when Sultan Abu Bakar paid a visit to Constantinople (Adam, 1992, p. 4)..13 She was the fourth wife of Dato Ja'afar. From the marriage of Dato Ja'afar, Rukiye Hanim bore eight children on the basis of information from Ramlah Adam: Aishah, Kamariah, Dato Onn, Malik, Azizah, Muhammad, Ahmad, Yahya" (Adam, 1992, p. 5). Datuk Jaafar Onn also confirms that his grandmother gave birth to eight children (Datuk Jaafar Onn, personal communication, February 21, 2014, Petaling Jaya).

Another interesting data point in the account of Prof. Ozay is related to the arrival date of Rukiye Hanim. If it is considered that Rukiye Hanim was born in 1864, the account of Prof. Ozay about the year Rukiye Hanim was brought to Johor on the basis of acquaintance collected during the interview is not logical. Instead of giving an exact date or year, Prof. Ozay mentions

11 Note: The same statements can be found in another paper. See.: Colachal (2014).

12 In regard with Jambi case See.: Locher-Scholten (1994, p. 122).

13 For one of the visits of Sultan Abu Bakar, See.: Başbakanlık Osmanlı Arşivleri [BOA] (n.d.). 
the middle of the 1860s as a possible date (Ozay, 1990, p. 28). In this context, the version accounted by Ramlah Adam is more reliable. Another contradiction appears in relation to whether the visit of Sultan Abu Bakar happened in 1879 or not. As an alternative reasoning, it is possible that though Abu Bakar was present in Constantinople in 1866, the concubines were later sent in $1879 .{ }^{14}$ The assumption regarding the Sultan of Johor's visit to Constantinople is highlighted in the novel titled Surat-Surat Perempuan Johor by Faisal Tehrani. He mentions that the Sultan had been to Constantinople during his visit to Europe in 1893-1895. The visit of the Sultan of Johor to Constantinople during his travel to Europe would have been the mark of an effective beginning between two states (Tehrani, 2007, p. 125).

It is allegedly asserted that these concubines were presented by Abdulhamit II, the Sultan of the Ottoman State to Abu Bakar the Sultan of Johor State. During his presence in Constantinople, Abdulhamit II honoured his guest with a piece of Mecidiye Gold (Ramli, 2011, p. 111; Tehrani, 2007, p. 127). Despite the Sultan's visit to Constantinople, when the age of Rukiye Hanim is considered, the presentation of this lady was impossible at the exact time of his visit. The Legacy of Honour, a biography of the Dato Onn family, written by Zainah Anwar, argues that Rukiye Hanim was born in 1864. This fact eliminates the possibility of Rukiye Hanim accompanying Sultan Abubakar back to Johor. As a result, this presentation was not realized during the visit of the Sultan of Johor to Constantinople, instead Rukiye and Hatice Hanim were sent separately to Johor, as expressed by Mohamed Abid, who was the Private Secretary of Dato Onn bin Jaa'far (Mohamed Abid, personal communication, August 27, 2013, Bukit Damansara, Kuala Lumpur). It is also interesting to inquire into their journey from Constantinople to Johor. If similar travels are considered, there is no doubt that their travel by ship passed through the Suez Channel, which was opened in 1869, stopped in some port cities of India and Sri Lanka and at last arrived in Singapore.

Here it is appropriate to share some information about the tradition in the Ottoman Palace pertaining to the age of concubines. As strongly argued by Ekrem Saltık the Ottomans did not give any child-aged girls as concubines. After all the disputes around the arrival of Rukiye and Hatice Hanim we pay attention to the statement of Rukiye Hanim's grandson. With regard to this, Datuk Jaafar Onn asserts that Abu Bakar visited Constantinople twice; the second visit happened in 1886. He also asserts that Rukiye and Hatice Hanim were sent to Singapore in 1887 (Datuk Jaafar Onn, personal communication, February 21, 2014, Petaling Jaya).

\section{Rukiye Hanim versus Hatice Hanim}

As mentioned in various sources there were two sisters, Rukiye and Hatice, presented as concubines by the Ottoman ruler to Sultan Abu Bakar of Johor. Until present, Rukiye Hanim has received the most interest. Of course, there is a cogent reason for this interest, such as the fact that Rukiye Hanim got married three times and she gave birth to eleven children from these marriages. On the other hand, Hatice Hanim gave birth to only two daughters.

14 Sultan Ebu Bakar of Johor State was known by his oft-visit to Europe and some Asian countries such as China and Japan. His visit to Constantinople was arranged by Al-Sagoff, a distinguished Arab descendant in Singapore. In fact, Al-Sagoff was appointed by Sultan Abdulhamit II to be first Ottoman Consul in Singapore. 
Datuk Jaafar Onn states that the graves of both sisters are in Mahmodiyyah Cemetery in Johor Bahru (Datuk Jaafar Onn, personal communication, February 21, 2014, Petaling Jaya).

In yet other sources, it becomes unclear whether the Sultan had any children from his marriage to Hatice. Some argue that they had two daughters named Azizah and Fatimah (Anwar, 2011, p. 63). However, Hikayat Johore asserts that they did not have children owing to the ending of this marriage in a short period of time.

If we reinstate the accounts of Prof. Ozay it is surprising that the interview which is supposed to be very reliable did not provide healthy information about dates. Though the accounts of Prof. Ozay are thought to endow originality and reliability on the basis of an interview, they reveal a gross mistake about her marriage with Sultan Abu Bakar. This mistake forces us to reconsider the reliability and authenticity of the interviewee. But in reality, Abu Bakar married Hatice Hanim while he arranged Rukiye's marriage with his younger brother.

The second point is the marriages of Rukiye Hanim. As aforementioned, Prof. Ozay states that Rukiye Hanim's first marriage was with Ungku Abdul Majid, the younger brother of Sultan Abu Bakar and that she bore him three sons (Ozay, 1990, p. 28). Nevertheless, the works published in Malaysia both in English and Malay languages, emphasize that this marriage produced only two sons, named Abdul Aziz and Abdul Hamid (Anwar, 2011, p. 63).Ungku Abdul Aziz bin Abdul Majid was appointed as the Chief Minister of Johor in the second part of 1930s (Abid, 2003, p. 23). His appointment is a significant detail to be mentioned so as to see the relationship among the families in the Palace circle. When Ungku Abdul Majid passed away on March 28th, 1889, there is no mention of the name of Rukiye Hanim in the newspaper, though some other names do appear. ${ }^{15}$ Additionally, the cause of his death is also not explained. Haji Dato Ja'faar was appointed by the Sultan to his place in the state administration (Anwar, 2011, p. 39).

Though disagreement emerged in the number of children, we should draw attention to the similarity of the names of the children with the names of Ottoman Sultans. When the time comes to talk about Prof. Ungku Abdul Aziz, late Rector of Universiti Malaya (UM), the turmoil again appears. As a general disposition, Rector Ungku Abdul Aziz is supposed to be the son of Rukiye Hanim. This is a gross mistake stemmed from a simplistic approach which might be called as a 'copycat suicide'. The fact is that Abdul Hamid, the son of Rukiye Hanim, gave his brother's name -Abdul Aziz- to his own son as well. It means that the late Rector of UM was the grandson of Rukiye Hanim. Though it will be elaborated below, as an initial reminder it should be accentuated that the Rector of UM was born from the Armenian wife of Ungku Abdul Hamit in London (Anwar, 2011, p. 68).

It should be remembered here that giving distinguished Sultans' names to children was not a new habit. In the context of Abdul Hamid and Abdul Aziz being given names of children in the Johor Sultanate family is not surprising. Though it attests to a sort of relation with the Ottomans, it does not augur for a substantial reference of a strong political or military bond. This is just a reflection of a sort of respectfulness to the successful leaders in the Islamic world. As seen in the very early centuries, such as the era of the Sultanate of Samudra Pasai giving Middle Eastern Sultans' names to children in palace circles has been a common practice in the Malay region. 


\section{The Life of Rukiye Hanim in Johor}

Before talking about her marriages, we wish to touch on some issues inspired from her pose in some photographs, reflecting some instances in her life in Johor. Some works strongly emphasize the beauty of Rukiye Hanim. For instance, Ramlah Adam describes her as 'jelita', meaning 'pretty woman' (Adam, 1992, p. 6). There are a variety of photographs taken not only with Dato Ja'faar bin Muhammad but also with extended family as well as some taken during ceremonies with the presence of Western guests, including British officials from Singapore. She is seen to be of medium height, fair colour, dark straight hair, and black eyes which represent a typical Middle Eastern, West Asian or Caucasian type. Striking in all these photos is the gloomy looking Rukiye Hanim (Anwar, 2011, pp. 6, 36, $38,62)$. She appears to be in a place where she did not feel she belonged. In this junction, it is better to refer to an account by Snouck Hurgronje regarding the Circassian 'slaves', though not necessarily talking about the Southeast Asian context, whom he mentioned to have come via Constantinople and to be of higher cost than the other slaves. Furthermore, he adds that "the female Circassian slaves are pretentious concubines" (Hurgronje, 2007, p. 15).

First of all, Rukiye Hanim is seen not to have worn a headscarf in all the photographs. In fact, Rukiye Hanim is not the exception in this matter. All the female members of the Palace family and elite circles in the photographs seen in the work titled Legacy of Honour are without headscarves. It might be regarded that this was a mainstream dress code followed by the Palace authorities. When asked about this issue during the interview, Zainah Anwar said that it was common then. In addition, she stated that a Malay Muslim woman's dress code was different than the current contemporary era (Zainah Anwar, personal communication, December 23, 2011, Petaling Jaya).

In addition, another interesting visual point is that Rukiye Hanim, who is reputed to be a beautiful lady, appears sullen without exception in every photograph. She looks like an individual who has lost her geography and her identity. Furthermore, she gives an impression that she did not feel a sense of belonging to the social environment she was in.

\section{Marriages of the Sisters}

Her marriages are described by Faisal Tehrani, the writer of Surat-Surat Perempuan Johor as:

“... Johor akan menghasilkan belih daripada Ungku Abdul Aziz, lebih daripada Dato Onn, lebih daripada Naquib al-Attas yang semuanya punya jalur yang sama, iaitu dari Ruqayyah Hanum... Johor melahirkan manusia-manusia penting dalam sejarah negara kita dari satu rahim." (Tehrani, 2007, p. 12).

Conversely, the presence of Hatice Hanim was always underestimated in related works. As seen in the quotation above, while the writer focuses on the story of Rukiye Hanim, it is hardly possible to hear of Hatice Hanim's life in Johor Sultanate. What is known is merely confined to her marriage with Sultan Abu Bakar.

Sultan Abu Bakar was married to Hatice Hanim (Che Khatijah Hanum), allegedly the sister of Rukiye Hanim, on 24 February 1891. This was his fourth marriage after Ungku Wan Chik, 
a lady from Pahang palace circle (1858); Cecilia Catherine Lange, a Danish-Chinese (1870); Wong Ah Gew, a Chinese descent (1885) (Ramli, 2011, p. 37). Hence, Paridah Abd. Samad argues that this marriage happened in the year 1892 (Abd. Samad, 2011, p. 21).

\section{Rukiye Hanim's Marriages}

\section{First Marriage}

Rukiye Hanim, whose name is mentioned in some sources as Rusaya, was married three times. Her first marriage was with Ungku Abdul Majid bin Temengung Ibrahim, the younger brother of Sultan Abu Bakar. In fact, Sultan Abu Bakar himself arranged this marriage for his brother, and two sons named Ungku Abdul Aziz Ungku Abdul Hamid were born into the family (Adam, 1992, p. 5; Anwar, 2011, pp. 31, 63; Siew Im, 1998, p. 20). ${ }^{16}$ Abdul Aziz, the first child, was born to the family in 1888, when Rukiye Hanim was 24 years old. If it is considered that her husband died on $28^{\text {th }}$ March, 1889 , as mentioned above, she gave birth to her second child in less than two years time.

\section{Second Marriage}

She married Syed Abdullah Syed Mohsin Al-Attas, who was originally a Hadramawt -Yamani, but migrated from Bandung to Singapore. Roquaiya Hanim (alternate spelling) bore him only one child, who was named Syed Ali Syed Abdullah al-Attas (Abd. Samad, 2011, p. 21). This marriage just lasted several weeks and from this marriage, Syed Ali was born (Anwar, 2011, p. 68)..$^{17}$ Though it is yet to be known when this marriage occurred, it must have been during a time when Sultan Abu Bakar was out of Johor for a travel or visit. This is crucial, since as remarked in some accounts that Sultan Abu Bakar was not happy about this marriage, though the reason was not clear, when he was informed of it. Due to the Sultan's reaction to the marriage, Abdullah Al-Attas was coerced into divorcing Rukiye Hanim after some time. It is understood that because of the palace involvement and scenario about the future of Rukiye Hanim, the marriage was ended in a short period of time, possibly in 1892 (Adam, 1992, p. 6; Seben, 2014, p. 15; Siew Im, 1998, p. 20). In order to understand the reaction of Sultan Abu Bakar, an event that occurred in the mansion of Dato Jaa'far bin Muhammed in Bukit Senyum should be examined. During a dinner, Syed Abdullah took off his wrap and put it on Dato Jaa'far. This was a symbolic expression that meant that Syed divorced Rukiye Hanim and Dato Jaa'far would look after her (Anwar, 2011, p. 68). There is no doubt that this was performed under the directions of Sultan Abu Bakar. The motive behind the Sultan's intervention basically must have been of great concern for the future of his nephews, say, the sons of his younger brother.

16 Note. Some sources mistakenly mentioning the number of couple's children as three, instead two. See.: Kayadibi (2011)., p. 200.

17 Seyyid Ali is the father of Professor Dr. Seyd Huseyin Al-Attas and Prof. Dr. Syed Naqib Al-Attas. (See: "Mengimbau Lembaran Sejarah Hubungan Johor-Turki" (2007, p. 25). (Note: The information of how long they remained married came from a grandson of Rukiye Hanim who requested anonimty.) 


\section{Third Marriage}

She married her third husband Dato Jaafar Haji Mohamad. Dato Jaafar was the second strongest man in terms of political power after Sultan Abu Bakar in the Sultanate. He was also the acting ruler of the Sultanate while Sultan Abu Bakar was abroad. Dato Jaafar was also appointed as the first Menteri Besar of Johor (Abd. Samad, 2011, p. 21). He also had familial connections.

By this development, Rukiye Hanim was married to Dato Jaa'far who held the post of prime minister and had ties with palace circles in Johor and Pahang. Again, there is no reliable data about the date of this marriage. Hence, it can be guessed that it happened in 1892. While it was the fourth marriage of Dato Jaa'far (Anwar, 2011, p. 62), and he was 55, Rukiye Hanim was almost 28 years old when they got married. If we consider the age gap between Dato Jaa'far (born 1837) and Rukiye Hanim (1864), it might be assumed that the Sultan was concerned about the future of both Rukiye Hanim and his nephews and intended Dato Jaa'far to pay enough care for the family living in the vicinity of the palace. This marriage continued for almost 12 years and produced eight children in total. However, from her previous marriages Rukiye Hanim had three more children. Dato Jaa'far also adopted Rukiye Hanim's previous three children as stepsons (Anwar, 2011, p. 63).

Prof. Ozay mentions that Dato Jaa'far did not belong to palace families; he was a commoner. The latter was a title given to outsiders who were appointed for some missions in the administration and of course, related to the palace circles. Hence, there is a strong possibility that the latter had a considerable bond with the Malay Sultanate families (Ozay, 1990, p. 28). Despite this argumentation, Dato Jaa'far was a distinguished official and drew attention because of his administrative skills and very close relationship with Sultan Abu Bakar. The latter trusted him so much that whenever left the country, the responsibility over state issues was given to Dato Jaa'far. On the other hand, Datuk Jaa'far Onn states that his lineage from his father's side traces back to the Malacca Sultanate. The family, generation by generation, produced individuals that took part in the administration of both the Malacca and the Johor-Riau Sultanates (Datuk Jaafar Onn, personal communication, February 21, 2014, Petaling Jaya).

Dato Jaa'far bin Mohammad's fourth wife, Rukiye Hanim, was described as "a beautiful Turkish lady" who gave birth to eight of his children. These are, in order, Aishan (Mak Bukit), Kamariah (Mak Anjang), Onn (Menteri Besar), Malik (passed away during very early months of his infancy), Azizah, Mohamed, Ahmad Keppel and Yahya (Anwar, 2011, pp. 63, 79).

Some sources mention that Dato Onn, ${ }^{18}$ who would become a great intellectual, statesman and the founder of UMNO, was the third child in the family (Anwar, 2011, p. 32), instead Pamela Ong argues he was the fourth one (Siew Im, 1998, p. 19). A year after his birth in 1895 , the family moved to a mansion built in Bukit Senyum (Anwar, 2011, p. 79) which was later converted into a museum. The mansion, built on a hilly site, was then overlooking the city centre and the Strait of Johor. Dato Jaa'far requested this land from the Sultan 
and the construction of the mansion was completed in three years time. It represented an architectural design similar to the era of Elizabeth II and Dato Jaa'far spent the rest of his life there until he passed away in 1919 (Anwar, 2011, p. 57).

This mansion is no doubt full of memories of Rukiye Hanim who lived in it until she passed away, after giving birth to Yahya, her last son, in 1904 (Anwar, 2011, p. 63). ${ }^{19}$ This is another controversial issue since Ramlah Adam and Pamela Ong Siew Im argue that the year Rukiye Hanim passed away is 1902 (Adam, 2005, p. 6; Siew Im, 1998, p. 23). It is observed that Dato Jaa'far soon got married with Selamah Ambak and he named his newly born daughter Rukiye Hanim, thereby asserting his love of his previous wife (Anwar, 2011, p. 58, 63). In a similar way, the name of Rukiye has been continuously given to new female members of the family. For instance, Tun Hussein Onn, the elder son of Dato Onn, gave the name of his grandmother to his eldest daughter (Anwar, 2011, p. 186).

\section{Arrangement of Marriage Among Cousins}

There seems to have been a grandeur project by Sultan Abu Bakar for the future of his daughters from the marriage with Hatice Hanim, Rukiye Hanim's sister. After a while, he arranged inter-marriages between cousins. In these terms, though Ungku Abdul Aziz married Azizah, they did not have a child from this marriage. It was known that Abdul Aziz would be the sixth Prime Minister (Menteri Besar) of the Johor State. Despite the Johor Sultan's arrangements, the marriage between Ungku Abdul Hamid and Fatma was not exercised for some unknown reason. It was remarked in some accounts that Unku Abdul Hamid was despondent after his failure to marry Fatma and he left for London some time later. What is striking and would later on be a crucial reason to cause misunderstandings, at least in some circles, is related to his marriage in London. Ungku Abdul Hamid's married an Armenian woman and he returned to Johor with his child after her death (Anwar, 2011, p. 63).

The above mentioned 'misunderstanding' pertains to Ungku Abdul Hamid's son who was named Abdul Aziz after his uncle and was later to take the position of rector at University Malaya (UM). It must be remarked that there are two Abdul Aziz; the first is the son of Rukiye Hanim and the second is the son of Ungku Abdul Hamid from his Armenian wife. Though this family tree can be accurately retraced, some circles seem to have missed a line related to Armenian bond and come to a direct conclusion that the Rector of UM was the direct descent of Rukiye Hanim. In fact, the mentioned rector was not Ungku Abdul Majid, the son of Rukiye Hanim, instead the son of Abdul Hamid who married an Armenian lady during his stay in London. As a conclusion, the rector of UM was the grandson of Rukiye Hanim, born to an Armenian lady and not a descendant of Turkish blood, but a mixture of Caucasian and Armenian blood from his mother and grandmother.

19 Rukiye Hanim was buried in the graveyard complex in Mahmudiyyah, Johor Bahru on the basis of information of Datuk Jaafar Onn, grandson of Rukiye Hanim. (Datuk Jaafar Onn, personal communication, February 21, 2014, Petaling Jaya.) 


\section{The Identity of Rukiye Hanim}

It is understood that Rukiye Hanim was granted a sort of nobility status such as Datin which has normally been given to distinguished individuals around the Palace (Anwar, 2011, p. 36). Some arguments emerge here related to the social status of Rukiye Hanim. It is a strong statement that if she had been a courtier, she would have been given 'Sultanah', instead of 'Datin'.

Owing to her being the wife of Haji Jaafar bin Mohamad, the second man of the Sultanate, who was politically of paramount importance after the Sultan, she was invited to all sorts of ceremonies conducted for a variety of reasons including the ones held for foreign dignitaries. For instance, during an official visit of Chulalongkorn, the King of Siam, to the Sultanate, Rukiye Hanim was photographed with others in the Tyersall Palace, one of the distinguished properties in Singapore belonging to Johor Sultanate (Anwar, 2011, p. 38).

Though it is assumed to be a detail, the first meeting of Dato Jaa'far and Rukiye Hanim inevitably deserves to be researched. Dato Jaa'far was known to be very close to the Sultan and he accompanied the latter during visits paid to foreign countries. In particular, before the death of Ungku Abdul Aziz, younger brother of the Sultan in 1889, it is remarked that Dato accompanied the Sultan on almost all visits abroad. For instance, his name can be found on the list of participants to the trip paid to Europe in 1866 (Anwar, 2011, p. 40). Despite the fact that there has not been any written reference, it might be guessed that during the Sultan's visit to Constantinople, Dato accompanied him. Hence, Datuk Jaafar Onn asserts that his grandfather accompanied Sultan Abu Bakar during his visit to Constantinople (Datuk Jaafar Onn, personal communication, February 21, 2014, Petaling Jaya).

\section{Conclusion}

There is no doubt that the second part of the 19th century witnessed drastic changes in almost all social institutions in every corner of Islamic world. Abdulhamit II was trying to accentuate political stability of the Ottoman State particularly against the interventions of leading power circles in Europe. On the other hand, the Johor Sultanate, while not colonized by the British in the exact meaning of the word, was under close scrutiny of the latter owing to the closer border relations between Johor State and Singapore Island (Ramanathan, 2000, p. 109). The Johor administration, under the control of the Palace, was in the process of modernization as a reaction or accommodation to the political dominion of the British presence in the region. Of course, it is indubitable that the Johorians' wished to collect the fruits of fast-growing developmental entrepreneurship in the context of business opportunities and investments of foreign individuals and companies. As a reflection of the British influence, the ruler of Johor State, who was called Maharaja, was appointed by the British as Sultan of Johor ("Monday, 25th June", 1877, p. 6; Winstedt, 1992, p. 125). In this context, it is convincingly arguable that the Johor Sultan was compatible with the British Colonial officials in Singapore.

In regard to this, while there is no satisfying and convincing information about the two concubines and accounts of their life, these two concubines are presented as the 
representatives of the Ottoman family. Further, there is no doubt that this sensational issue seems to have become a vehicle for an imagined relation between two regions. There is no doubt that the media aspect of this concubine case is attractive enough to exaggerate, to some or larger extent. For all these reasons, this issue must be scrutinized academically based on the authentic references written in Malaysia and Turkey in the last few decades. Considering the issue cited above, this article ought to be regarded to have a critical stance in a time of relatively increasing recognition of both countries in current contemporary era.

\section{References}

Abd. Samad, P. (2011). The myth of dato' Onn Jaafar: The forgotten hero. Kuala Lumpur: Partisan Publication.

Abdullah. A. (2004). Biografi dato' Onn: Hidup Melayu [The biography of Dato Onn': Long live Malay]. Bangi: Penerbit Universiti Kebangsaan Malaysia.

Abdullah, A. R. T. (2011). Hikayat Johor dan tawarikh almarhum Sultan Abu Bakar [Hikayat Johor and the history of the Late Sultan Abu Bakar], Johor Bahru: Yayasan Warisan Johor.

Abid, M. (2003). Reflections of pre-independence Malaya (2nd ed.). Kuala Lumpur: Pelanduk Publications.

Adam, R. (1992). Dato' Onn Ja'afar: Pengasas Kemerdekaan [Dato' Onn Ja'afar: Initiatior of the independence]. Kuala Lumpur: Dewan Bahasa dan Pustaka.

Adam, R. (2005). Dato' Onn Ja'afar: Pengasas Kemerdekaan [Dato' Onn Ja'afar: Initiatior of the independence] (Cetakan keempat [4rth ed.]). Kuala Lumpur: Dewan Bahasa dan Pustaka.

Anwar, Z. (2011). Legacy of honour. Kuala Lumpur: Yayasan Mohamed Noah.

Armağan, M. (2007, 30 Eylül). Malezya kimliğinde Osmanlı damgası. Retrieved May 26, 2015, from http://www. zaman.com.tr/mustafa-armagan/malezya-kimliginde-osmanli-damgasi_787391.html.

Aymalı, Ö. (2014, 9 Ocak). Osmanlı-Malezya ilişkileri nasıl gelişti? Retrieved May 26, 2015, from http://www.dunyabulteni.net/?aType=haber\&ArticlelD=285731.

Başbakanlık Osmanlı Arşivleri. (t.y.), Y.PRK.BŞK. No: 30, 1310, L, 28, 8.

Borham, A. J. (2002). Ahkam syar'iyyah Johor: Kod undang-undang keluarga Islam kerajaan negeri Johor 1935 [Johor Syar'iyyah law code: Muslim family law in Johor state government 1935]. Skudai: Universiti Teknologi Malaysia.

Brookes, D S. (Ed.) (2008). The concubine, the princess, and the teacher: Voices from the Ottoman Harem. Austin: University of Texas Press.

Bugis. (n.d.). Retrieved May 27, 2015, from http://self.gutenberg.org/articles/bugis.

Colachal, A. R. (2014, January 13). Focus on Malaysia Turkey relations. Retrieved May 27, 2015, from https:// abdulrubb.wordpress.com/2014/01/13/focus-on-malaysia-turkey-relations.

Death of the Sultan of Johore. (1895, July 8). The Singapore Free Press and Mercantile Advertiser (1884-1942). Microfilm NL3157, Lee Kong Chian Reference Library.

Demir, N. Özcan (2003). Osmanlı Devletinde harem kurumu. Sosyoloji Konferansları Dergisi [Istanbul Journal of Sociological Studies], 28. Retrieved May 27, 2015, from www.journals.istanbul.edu.tr/iusoskon/../1023005746.

Haji Abdul Rahman, Mohd. T. (1987). Dato' Onn Jaafar: Tokoh nasionalis [Dato' Onn Jaafar: National hero]. Selangor: Pelanduk Publications.

Huen, P. L. P. (2009). Johor 1855-1957: Local history, local landscapes. Singapore: Straits Times Press.

Hurgronje, S. (2007). Mekka in the latter part of the $19^{\text {th }}$ century. Leiden: Brill.

Husain, S. (1985). Biografi perjuangan politik dato' Onn Ja'afar [Biography of political struggle of Dato' Onn Ja'afar]. Petaling Jaya: Fajar Bakti.

Husain, S. (1995). Sejarah Johor: Kaitannya dengan negeri Melayu [The history of Johor: Its relation with Malay state]. Shah Alam: Penerbit Fajar Bakti.

Idris, A., \& Kurtbağ, Ö. (2013). Malaysia-Turkey relations in history and today. Middle East Institute. Retrieved May 27, 2015, from http://www.mei.edu/profile/asmady-idris-and-\%C3\%B6mer-kurtba\%C4\%9F. 
Johore in the Sultan's absence. (1890, September 17). Straits Times Weekly Issue. Microfilm NL5210, Lee Kong Chian Reference Library.

Johore News. (1889, April 1). The Straits Times. Microfilm NL5051,Lee Kong Chian Reference Library.

Kayadibi, S. (2011). Judicial pluralism in the Malaysian legal system. In Ottoman connections to the Malay world: Islam, law and society, (ed.) S. Kayadibi, (pp. 186-210). Kuala Lumpur: the Other Press.

Locher-Scholten, E. (1994). Sumatraans Sultanaat en koloniale staat: De relatie Djambi-Batavia (1830-1907) en het Nederlandse imperialism. Leiden: KITLV Uitgeverij.

Mengimbau lembaran sejarah hubungan Johor-Turki. [Recalling the narration on history between Johor-Turkey]. (2007). Buletin Yayasan Warisan Johor, XIII (I-II).

Milner, A. C. (1986). The impact of the Turkish revolution on Malaya. Archipel, 31, 117-130.

Monday, 25th June. (1877, June 30). The Straits Times. Microfilm NL5046, Lee Kong Chian Reference Library.

Najib an Orang Bugis or an Orang Melayu [Najib, Is a Bugis or a Malay]. (2009, November 19). Retrieved May 27, 2015, from http://theunspunblog.com/2009/11/19/najib-an-orang-bugis-or-an-orang-melayu.

Old treaties \& documents of Malaysia: 1791-1965. (2008). Kuala Lumpur: Institut Terjemahan Negara Malaysia.

Ozay, M. (1990). Islamic identity and development: Studies of the Islamic periphery. Kuala Lumpur: Forum.

Özay, M. (2012, 27 Temmuz). Onn ailesi anlaşılmadan Malezya anlaşılmaz. Retrieved May 26, 2015, from http:// www.dunyabizim.com/?aType=haberYazdir\&ArticleID=10533\&tip=haber.

Özcan, Z. (2011, 21 Mart). Malezya'nın Osmanlıları. Retrieved May 27, 2015, from http://www.aksiyon.com.tr/ zafer-ozcan/malezya-nin-osmanlilari-528923.

Perdana Leadership Foundation. (1983, May 13). Prime Minister, Turkey. Retrieved May 26, 2015, from http:// www.perdana.org.my/perdana-library/search-our-resources.

Popper, W. (1957). Egypt and Syria under the Circassian Sultans: 1382-1468 (Systematic notes to Ibn Taghri Birdi's chronicles of Egypt). Berkeley, CA: University of California Press.

Ramli, A. R. (2011). Sejarah adat istiadat Diraja Johor [History of royal custom of Johor]. UTM, Johor Bahru.

Ramanathan, N. N. N. (2000). Johore and the origins of the British Control: 1895-1914. Kuala Lumpur: Arenabuku.

Reid, A. (1967). "Nineteenth century Pan-Islam in Indonesia and Malaysia”, The Journal of Asian Studies, 26(2), 267-283.

Saltık, E. (2011). Güney Asya ve Uzak Doğu'da Osmanlı izleri: Yedi Ülke Bir Medeniyet. İstanbul: Nesil Yayınları.

Saltık, E. (2012a). Çerkez Cariye Rukiye; Malezya'da Bir Osmanlı Nesli (Rukiye Hanim: Circassian Concubine and Ottoman Descendants Ruling Malaysia). Yedikıta Dergisi, 41, 12-22.

Saltık, E. (2012b, 8 Ocak). Çerkez Cariye Rukiye Hanim ve Malezya'yı Idare Eden Osmanlı Nesli-2. Retrieved May 27, 2015, from http://gizlenentarihimiz.blogspot.com/2012/01/cerkez-cariye-rukiye-hanm-ve-malezyay_08.html.

Seben, H. T. (2014). Singapur'daki ilk temsilciliklerimiz ve Başkonsolos Ahmed Ataullah Efendi. T.C. Singapur Büyükelçiliği. Retrieved May 27, 2015, from http://www.mfa.gov.tr/site_media/html/singapur_v3.pdf.

Siew Im, P. O. (1998). One man's will: A portrait of Dato' Sir Onn Bin Ja'afar. Penang: No publication house.

Stafford, P. (1998). Queens, concubines and dowagers: The king's wife in the early middle ages. London: Leicester University Press.

Şara Şatana, N. (2012, 2 Eylül). Rukiye ve Hatice Hanimlar. Retrieved May 26, 2015, from http://blog.milliyet.com. tr/rukiye-ve-hatice-hanimlar/Blog/?BlogNo=377203.

The Sultan of Johore in Germany. (1893, July 14). The Straits Times. Microfilm NL5055, Lee Kong Chian Reference Library.

Tehrani, F. (2007). Surat surat perempuan Johor [Letters of the Johor women]. Putrajaya (Malaysia): Aberdeen Books World.

Trock, C. A. (1979). Prince of Pirates: The temenggongs and the development of Johor and Singapore: 1784-1885. Singapore: Singapore University Press.

Winstedt, R. O. (1992). A History of Johore (1365-1941). MBRAS Reprints, Reprint No. 6, Second Reprint.

Zilfi, M. (2005). Thoughts on women and slavery in the Ottoman Era and historical sources. In A. el-Azhary Sonbol (Ed.), Beyond the exotic: Women's histories in Islamic societies (pp. 131-139). New York: Syracuse University Press. 